\title{
ANALISIS PENGARUH DIMENSI KUALITAS PELAYANAN TERHADAP KEPUASAN PELANGGAN APOTEK KIMIA FARMA RANTAUPRAPAT
}

\author{
Bayu Eko Broto \\ Program Studi Manajemen, Fakultas Ekonomi dan Bisnis \\ Universitas Labuhanbatu, Labuhanbatu, Sumatera Utara \\ e-mail: bayueb@gmail.com
}

\begin{abstract}
ABSTRAK
Tujuan penelitian ini adalah untuk mengetahui pengaruh bukti fisik, kehandalan, daya tanggap, jaminan, dan empati terhadap kepuasan pelanggan Apotek Kimia Farma Rantauprapat. Sampel dalam penelitian ini adalah 98 orang pelanggan Apotek Kimia Farma Rantauprapat. Pengujian dalam penelitian ini menggunakan uji validitas, uji reliabilitas, uji regresi linier berganda, uji normalitas data, uji multikolinieritas, uji heteroskedastitas, uji parsial, uji simultan, dan uji koefisien determinasi. Dari hasil pengujian didapatkan hasil bahwa variabel bukti fisik berpengaruh positif dan signifikan terhadap kepuasan pelanggan, dengan nilai t hitung adalah 5,134 dan signifikansi 0,000. Variabel kehandalan berpengaruh positif dan sangat signifikan terhadap kepuasan pelanggan, dengan nilai t hitung adalah 5,149 dan signifikansi 0,000. Variabel daya tanggap berpengaruh positif dan signifikan terhadap kepuasan pelanggan, dengan nilai $t$ hitung adalah 2,256 dan signifikansi 0,026. Variabel jaminan berpengaruh positif dan signifikan terhadap kepuasan pelanggan, dengan nilai $\mathrm{t}$ hitung adalah 8,448 dan signifikansi 0,000 . Variabel empati berpengaruh positif dan signifikan terhadap kepuasan pelanggan, dengan nilai t hitung adalah 9,289 dan signifikansi 0,000.
\end{abstract}

Kata kunci : Bukti Fisik, Kehandalan, Daya Tanggap, Jaminan, Dan Empati Kepuasan Pelanggan

\begin{abstract}
The purpose of this study was to determine the effect of physical evidence, reliability, responsiveness, assurance, and empathy to customer satisfaction at Kimia Farma Rantauprapat Pharmacy. The sample in this study were 98 Pharmacy customers at Apotek Kima Farma Rantauprapat. Tests in this study use the validity test, reliability test, multiple linear regression test, data normality test, multicollinearity test, hete roscedastity test, partial test, simultaneous test, and coefficient of determination test. From the test results obtained that the physical evidence variable has a positive and significant effect on customer satisfaction, with a calculated $t$ value of 5.134 and a significance of 0.000 . The reliability variable has a positive and very significant effect on customer satisfaction, with a $t$ value of 5.149 and a significance of 0.000. The responsiveness variable has a positive and significant effect on customer satisfaction, with the value of t arithmetic is 2.256 and the significance of 0.026. The guarantee variable has a positive and significant effect on customer satisfaction, with the value of t arithmetic is 8.448 and the significance of 0.000. Empathy variable has a positive and significant effect on customer satisfaction, with a calculated $t$ value of 9,289 and a significance of 0,000 .
\end{abstract}

Keywords: Physical Evidence, Reliability, Responsiveness, Assurance, and Customer 


\section{Satisfaction Empathy}

\section{A. PENDAHULUAN}

Apotek merupakan sebuah tempat yang melaksanakan kegiatan kefarmasian yang memiliki peranan penting sebagai untuk mendapatkan informasi mengenai obat. Kegiatan kefarmasian semakin berkembang belakangan ini, tidak terbatas hanya pada kegiatan menyimpan dan menyarahkan obat kepada pelanggan saja, akan tetapi ada interaksi dan komunikasi dengan konsumen, dengan pelaksanaan pelayanan menyeluruh yang dilakukan oleh tenaga farmasi.

Sering sekali ditemukan keluhan konsumen di apotek, dari waktu pelayanan yan lamban, kurangnya ketepatan dan keamanan obat yang diberikan kepada konsumen, dan juga kurang memadainya fasilitas apotek mulai dari ruang tunggu yang tidak terlalu banyak, kebersihan apotek, dan lokasi parkir yang tidak terlalu aman.

Standar pelayanan kefarmasian di apotek ada dikelompok pengelolaan sumber daya mencangkup, pengelolaan sumber daya manusia, sarana prasarana, sediaan farmasi dan pembekalan kesehatan lain dan administrasi. Pelayanan mencangkup pelayanan resep, edukasi dan promosi, serta pelayanan resedensial (Home Care).

Apotek Kimia Farma Rantauprapat yang beralamat di Jl. Ahmad Yani, Rantauprapat, Sumatera Utara, diharapkan bisa menjaga hubungan baik dengan pelanggan. Dimana parameter digunakan meliputi; tangibles, responsiveness, reliability, assurance, dan empathy.

Tujuan penelitian ini adalah untuk mengetahui pengaruh tangibles, responsiveness, reliability, assurance, dan empathy terhadap kepuasan pelanggan Apotek Kimia Farma Rantauprapat baik secara parsial maupun secara simultan.

\section{B. LANDASAN TEORI 1. Kualitas Pelayanan}

Menurut Tjiptono \& Chandra (2011), Konsep kualitas dianggap sebagai ukuran kesempurnaan sebuah produk atau jasa yang terdiri dari kualitas desain dan kualitas kesesuaian (conformance quality). Kualitas desain merupakan fungsi secara spesifik dari sebuah produk atau jasa, kualitas kesesuaian adalah ukuran seberapa besar tingkat kesesuaian antara sebuah produk atau jasa dengan persyaratan atau spesifikasi kualitas yang ditetapkan sebelumnya. 
Menurut definisi di atas dalam kata lain, kualitas adalah sebuah bentuk pengukuran terhadap suatu nilai layanan yang telah diterima oleh konsumen dan kondisi yang dinamis suatu produk atau jasa dalam memenuhi harapan konsumen.

Dari beberapa pendapat, dapat di ambil garis besar bahwa kualitas pelayanan adalah kemampuan suatu perusahaan dalam memenuhi harapan konsumen dengan memberikan pelayanan kepada konsumen pada saat berlangsung dan sesudah transaksi berlangsung.

\section{Dimensi Kualitas Layanan}

Menurut Parasuraman, Zeithaml, dan Berry dalam Tjiptono (2011) terdapat lima dimensi kualitas jasa yang dijadikan pedoman oleh pelanggan dalam menilai kualitas jasa, yaitu:

a. Berwujud (Tangible)

Penampilan fasilitas fisik, peralatan, dan personil.

b. Empati (Emphaty)

Syarat untuk peduli, memberi perhatian pribadi bagi pelanggan.

c. Keandalan (Reliability)

Kemampuan untuk melaksanakan jasa yang dijanjikan dengan tepat dan terpercaya.

d. Keresponsifan (Responsiveness)

Kemauan untuk membantu pelanggan dan memberikan jasa dengan cepat atau tanggap.

e. Keyakinan (Assurance)

Pengetahuan dan kesopanan karyawan serta kemampuan mereka untuk menimbulkan kepercayaan dan keyakinan.

\section{Kepuasan Pelanggan}

Menurut Kotler dan Keller (2009) kepuasan (satisfaction) adalah perasaan senang atau kecewa seseorang yang timbul karena membandingkan kinerja yang telah dipersepsikan produk (atau hasil) terhadap ekspektasi mereka. Jika kinerja gagal memenuhi ekspektasi, pelanggan akan tidak puas. Jika kinerja sesuai dengan ekspektasi, pelanggan akan puas. Jika kinerja melebihi ekspektasi, pelanggan akan sangat puas atau senang.

Berdasarkan definisi diatas dapat disimpulkan bahwa kepuasan konsumen merupakan sikap, penilaian dan respon emosional yang ditunjukkan oleh konsumen setelah proses pembelian / konsumsi yang berasal dari perbandingan kesannya terhadap 
kinerja aktual terhadap suatu produk dan harapannya, serta evaluasi terhadap pengalaman mengkonsumsi suatu produk dan jasa.

\section{Pengaruh antara Kualitas Pelayanan dengan Kepuasan Pelanggan}

Berdasarkan landasan teori di atas dapat diketahui bahwa dalam membangun landasan yang kuat dalam menjalin hubungan yang baik dengan konsumen dibutuhkan kualitas pelayanan yang berkualitas. Pelayanan (services) merupakan sesuatu yang tidak dapat diciptakan secara tiba-tiba melainkan harus dibentuk secara perlahan-lahan. Pelayanan (services) mengacu pada konsumen yang memegang dengan erat suatu ingatan unik dalam ingatannya terhadap suatu produk atau jasa.

Hal tersebut hampir sama dengan yang diungkapkan oleh Kotler dan Keller dan Armstrong (2010), yang menyatakan "Customer satisfaction is closely linked to quality. Quality has a direct impacton product performance and customer satisfaction. In the narrowes sense, quality can be defined as "freedom from defectors" but most customer's centered company go beyond this narrow definition of quality. Instead, they defined quality in terms of customer satisfaction".

Menurut jurnal dari Dian Tauriana (2012) yang menyatakan pelayanan berhubungan erat dengan bisnis jasa yang dilakukan dengan cara memberikan kepuasan dalam pelayanan kepada pelanggan perusahaan tersebut. Dalam hubungan antara kualitas pelayanan jasa, kepuasan pelanggan, dan retensi pelanggan, Guzzo (2010), menyebutkan dalam hasil penelitiannya bahwa pada industri hotel, kepuasan pelanggan secara garis besar berhubungan dengan kualitas pelayanan. Melalui analisis ini, Guzzo mengevaluasi tingkat kepuasan pelanggan secara keseluruhan (overall customer satisfaction level) pada setiap pelayanan yang tersedia. 


\section{Kerangka Berpikir Gambar 1 Kerangka Berpikir}

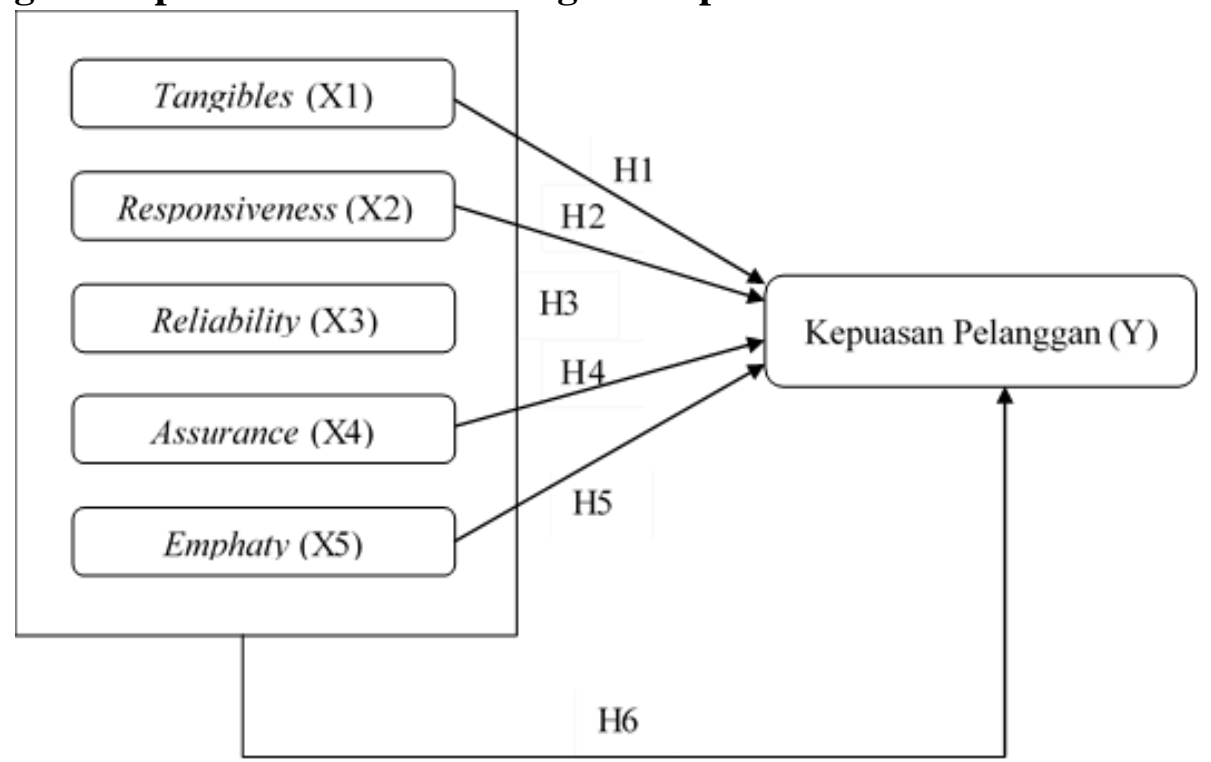

\section{METODE PENELITIAN}

Penelitian ini termasuk adalah penelitian noneksperimental dengan rancangan penelitian secara dekripsi dengan menggunakan analisis kuantitatif. Penelitian ini dilakuakn di apotek Kimia Farma Rantauprapat.

Penelitian ini menggunakan pendekatan surveys dimana proses pengambilan data dilakukan dengan cara menyebarkan kusioner dan melekakukan wawancara kepada responden.

Popolasi dalam penelitian ini di ambil pada tanggal 1 oktober 2019 hingga 31 oktober 2019 dengan jumlah banyak pelanggan di Apotek Kimia Farma Rantauprapat sebanyak 6,300 orang. Adapun metode pengambilan sampel dalam penelitian ini adalah metode convenience sampling dengan error sebanyak 10\%, maka sampel diambil sebanyak 98 pelanggan.

Penelitian ini menggunakan kuesioner. Instrumen yang digunakan untuk mengukur variabel penelitian ini dengan menggunakan skala likert 5 poin.

Teknik analis data dalam penelitian ini adalah uji validitas, uji reliabilitas, analisis regresi linier berganda, uji normalitas, uji multikolineritas, uji heteroskedastisitas, uji parsial, uji simultan, koefisien determinasi. 


\section{HASIL PENELITIAN DAN PEMBAHASAN 1. Analisis Data Penelitian}

Berdasarkan data penelitian yang telah dikumpulkan, maka diperoleh data tentang demografi responden yang terdiri dari:

Tabel 1 Proporsi Responden Dalam Sampel Menurut Jenis Kelamin

\begin{tabular}{|c|c|}
\hline Jenis Kelamin & Jumlah Responden \\
\hline Laki-laki & 41 \\
\hline Perempuan & 57 \\
\hline Jumlah & 98 \\
\hline
\end{tabular}

Sumber: Data diolah, 2020

Dari data responden berdasarkan jenis kelamin di atas jumlah responden laki-laki berjumlah 57 orang, Jumlah perempuan 41 orang. Maka mayoritas yang menjadi responden adalah laki-laki.

Tabel 2 Propersi Responden Dalam Sampel Menurut Usia

\begin{tabular}{|c|c|}
\hline Usia & Jumlah Responden \\
\hline $20-25$ & 25 \\
\hline $26-30$ & 29 \\
\hline$>30$ & 44 \\
\hline Jumlah & 98 \\
\hline
\end{tabular}

Sumber: Data diolah, 2020

Dari data responden berdasarkan usia dapat kita lihat dari tabel di atas bahwa responden yang berusia 20-25 tahun berjumlah 25 orang, Responden yang berusia 26-30 berjumlah 29 orang dan responden yang berusia $>30$ tahun berjumlah 44 orang. Maka mayoritas responden berdasarkan usia adalah $>30$ tahun. 2. Uji Kualitas Data

\section{a. Uji Validitas}

Nilai $r_{\text {tabel }}$ untuk uji dua sisi pada taraf kepercayaan 95\% atau signifikansi 5\% ( $\mathrm{p}=$ 0,05) dapat dicari berdasarkan jumlah responden atau $\mathrm{N}$. Oleh karena $\mathrm{N}=98$, maka derajat bebasnya (df) adalah $\mathrm{N}-2(98-2=96)$. Pada buku-buku statistik, nilai $\mathrm{r}$ tabel satu sisi pada $\mathrm{df}=96$ dan $\mathrm{p}=0,05$ adalah 0,20 . Butir pertanyaan dinyatakan valid jika jika nilai $r_{\text {hitung }}>r_{\text {tabel. }}$. Dari hasil out put di atas bahwa 5 pertanyaan untuk setiap variabel dengan $r_{\text {hitung }}>r_{\text {tabel }}$ atau $r_{\text {hitung }}>0,20$. Berdasarkan tabel di bawah maka analisis out-put pada setiap pertanyaan 1-5 dari setiap variabel dengan nilai $r_{\text {hitung }}>0,20$ maka dinyatakan valid. Kesimpulannya bahwa semua butir pertanyaan pada semua variabel adalah valid. 
Tabel 3 Uji Validitas Variabel Bukti Fisik

\begin{tabular}{|c|c|c|c|}
\hline Indikator & Nilai r Hitung & Nilai r Tabel & Keputusan \\
\hline BF1 & 0,794 & 0,20 & Valid \\
\hline BF2 & 0,758 & 0,20 & Valid \\
\hline BF3 & 0,798 & 0,20 & Valid \\
\hline BF4 & 0,783 & 0,20 & Valid \\
\hline BF5 & 0,763 & 0,20 & Valid \\
\hline
\end{tabular}

Sumber: Data diolah dengan menggunakan SPSS 25, 2020.

Tabel 4 Uji Validitas Variabel Kehandalan

\begin{tabular}{|c|c|c|c|}
\hline Indikator & Nilai r Hitung & Nilai r Tabel & Keputusan \\
\hline K1 & 0,809 & 0,20 & Valid \\
\hline K2 & 0,769 & 0,20 & Valid \\
\hline K3 & 0,777 & 0,20 & Valid \\
\hline K4 & 0,794 & 0,20 & Valid \\
\hline K5 & 0,768 & 0,20 & Valid \\
\hline
\end{tabular}

Sumber: Data diolah dengan menggunakan SPSS 25, 2020.

Tabel 5 Uji Validitas Variabel Daya Tanggap

\begin{tabular}{|c|c|c|c|}
\hline Indikator & Nilai r Hitung & Nilai r Tabel & Keputusan \\
\hline DT1 & 0,805 & 0,20 & Valid \\
\hline DT2 & 0,777 & 0,20 & Valid \\
\hline DT3 & 0,809 & 0,20 & Valid \\
\hline DT4 & 0,783 & 0,20 & Valid \\
\hline DT5 & 0,766 & 0,20 & Valid \\
\hline
\end{tabular}

Sumber: Data diolah dengan menggunakan SPSS 25, 2020.

Tabel 6 Uji Validitas Variabel Jaminan

\begin{tabular}{|c|c|c|c|}
\hline Indikator & Nilai r Hitung & Nilai r Tabel & Keputusan \\
\hline $\mathrm{J} 1$ & 0,778 & 0,20 & Valid \\
\hline $\mathrm{J} 2$ & 0,782 & 0,20 & Valid \\
\hline $\mathrm{J} 3$ & 0,743 & 0,20 & Valid \\
\hline $\mathrm{J} 4$ & 0,762 & 0,20 & Valid \\
\hline $\mathrm{J} 5$ & 0,808 & 0,20 & Valid \\
\hline
\end{tabular}

Sumber: Data diolah dengan menggunakan SPSS 25, 2020. 
Tabel 7 Uji Validitas Variabel Empati

\begin{tabular}{|c|c|c|c|}
\hline Indikator & Nilai r Hitung & Nilai r Tabel & Keputusan \\
\hline E1 & 0,800 & 0,20 & Valid \\
\hline E2 & 0,775 & 0,20 & Valid \\
\hline E3 & 0,772 & 0,20 & Valid \\
\hline E4 & 0,809 & 0,20 & Valid \\
\hline E5 & 0,783 & 0,20 & Valid \\
\hline
\end{tabular}

Sumber: Data diolah dengan menggunakan SPSS 25, 2020.

Tabel 7 Uji Validitas Variabel Kepuasan Pelanggan

\begin{tabular}{|c|c|c|c|}
\hline Indikator & Nilai r Hitung & Nilai r Tabel & Keputusan \\
\hline KP1 & 0,775 & 0,20 & Valid \\
\hline KP2 & 0,774 & 0,20 & Valid \\
\hline KP3 & 0,795 & 0,20 & Valid \\
\hline KP4 & 0,786 & 0,20 & Valid \\
\hline KP5 & 0,795 & 0,20 & Valid \\
\hline
\end{tabular}

Sumber: Data diolah dengan menggunakan SPSS 25, 2020.

\section{b. Uji Reliabilitas}

Tingkat reliabilitas dengan Alpha Cronbach diukur dari skala 0 sampai 1, sebagaimana tercantum pada tabel berikut ini:

Tabel 8 Tingkat Reliabilitas Berdasarkan Nilai Alpha

\begin{tabular}{|c|c|}
\hline Alpha & Tingkat Reliabilitas \\
\hline 0,00 s.d 0,20 & Kurang Reliabel \\
\hline$>0,20$ s.d 0,40 & Agak Reliabel \\
\hline$>0,40$ s.d 0,60 & Cukup Reliabel \\
\hline$>0,60$ s.d 0,80 & Reliabel \\
\hline$>0,80$ s.d 1,00 & Sangat reliabel \\
\hline
\end{tabular}

Tabel 9 Uji Reliabilitas Variabel

\begin{tabular}{|c|l|c|c|c|}
\hline No & \multicolumn{1}{|c|}{ Variabel } & Cronbach's Alpha & Nof Item & Kesimpulan \\
\hline 1 & Bukti fisik & 0,913 & 5 & Sangat reliabel \\
\hline 2 & Kehandalan & 0,915 & 5 & Sangat reliabel \\
\hline 3 & Daya tanggap & 0,918 & 5 & Sangat reliabel \\
\hline 4 & Jaminan & 0,911 & 5 & Sangat reliabel \\
\hline 5 & Empati & 0,917 & 5 & Sangat reliabel \\
\hline 6 & Kepuasan pelanggan & 0,916 & 5 & Sangat reliabel \\
\hline
\end{tabular}

Sumber: Data diolah dengan menggunakan SPSS 25, 2020. 
Berdasarkan nilai Alpha pada kolom Cronbach's Alpha pada tabel di atas, dimana variabel bukti fisik, kehandalan, daya tanggap, jaminan, empati, dan kepuasan pelanggan besarnya nilai Cronbach's Alphanya adalah 0,913, 0,915, 0,918, 0,911, 0,917, 0916 sehingga dinyatakan variabel bukti fisik, kehandalan, daya tanggap, jaminan, empati, dan kepuasan pelanggan adalah sangat reliabel karena berada diantara 0,80 s.d 1,00.

\section{c. Analisis Regresi Linier Berganda Tabel 10 Hasil Rregresi Berganda Coefficients ${ }^{a}$}

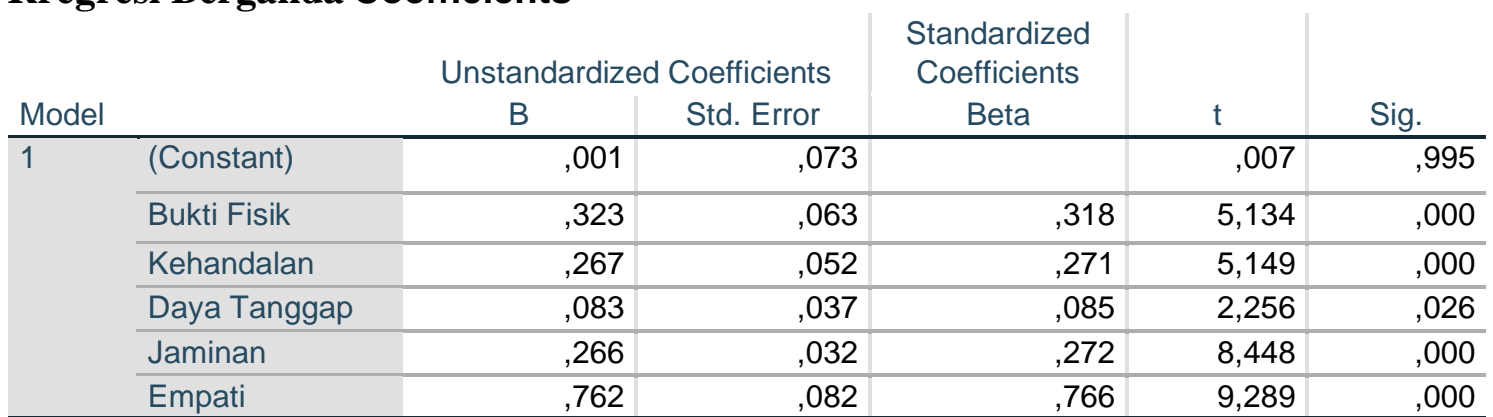

a. Dependent Variable: Kepuasan Pelanggan

Sumber: Data diolah dengan menggunakan SPSS 25, 2020.

Berdasarkan dari hasil analisa regresi output SPSS pada tabel diatas, persamaan regresi yang dihasilkan dibuat persamaan regresi yang terbentuk dalam model yaitu kepuasan pelanggan $=0,001+0,323 \mathrm{X}_{1}+0,267 \mathrm{X}_{2}+0,083 \mathrm{X}_{3}+0,266 \mathrm{X}_{4}+0,762 \mathrm{X}_{5}+\varepsilon$.

Adapun arti dari persamaan tersebut adalah sebagai berikut:

a. Koefisien bukti fisik artinya, bukti fisik berpengaruh positif terhadap kepuasan pelanggan Apotek Kimia Farma Rantauprapat.

b. Koefisien kehandalan artinya, kehandalan berpengaruh positif terhadap kepuasan pelanggan Apotek Kimia Farma Rantauprapat.

c. Koefisien daya tanggap artinya, daya tanggap berpengaruh positif terhadap kepuasan pelanggan Apotek Kimia Farma Rantauprapat.

d. Koefisien jaminan artinya, jaminan berpengaruh positif terhadap kepuasan pelanggan Apotek Kimia Farma Rantauprapat.

e. Koefisien empati artinya, empati berpengaruh positif terhadap kepuasan pelanggan Apotek Kimia Farma Rantauprapat 


\section{d. Uji Normalitas Gambar Uji Normalitas}

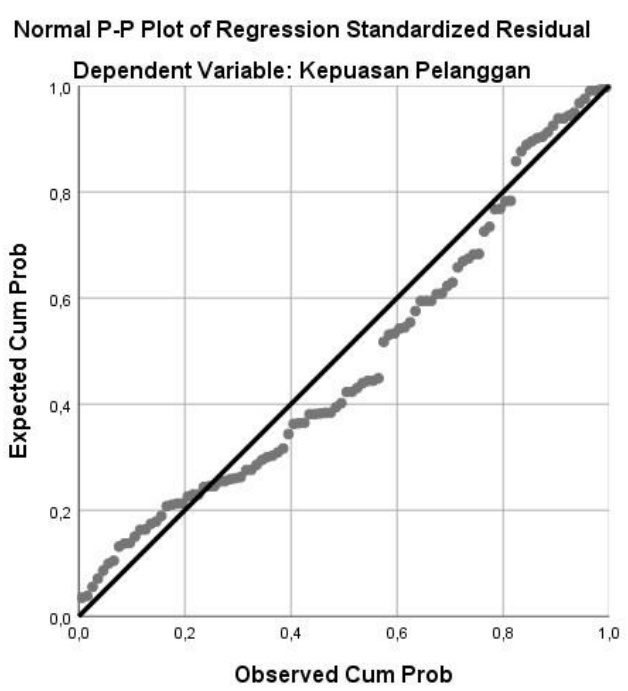

Sumber: Data diolah dengan menggunakan SPSS 25, 2020.

Dilihat dari gambar di atas, gambar P-Plot terlihat titik-titik mengikuti dan mendekati garis diagonalnya, sehingga dapat disimpulkan bahwa model regresi memenuhi perkiraan normalitas.

\section{e. Uji Multikolinearitas Tabel 11 Uji Multikolinearitas}

Coefficients $^{\mathrm{a}}$

\begin{tabular}{|c|c|c|c|c|c|c|c|c|}
\hline \multirow{2}{*}{\multicolumn{2}{|c|}{ Model }} & \multirow[b]{2}{*}{ B } & \multirow{2}{*}{$\begin{array}{l}\text { dardized } \\
\text { cients } \\
\text { Std. } \\
\text { Error } \\
\end{array}$} & \multirow{2}{*}{$\begin{array}{c}\text { Standardized } \\
\text { Coefficients } \\
\text { Beta } \\
\end{array}$} & \multirow[b]{2}{*}{$\mathrm{t}$} & \multirow[b]{2}{*}{ Sig. } & \multicolumn{2}{|c|}{ Collinearity Statistics } \\
\hline & & & & & & & Tolerance & VIF \\
\hline 1 & (Constant) &, 001 & ,073 & & ,007 & ,995 & & \\
\hline & Bukti Fisik & ,323 & ,063 & 318 & 5,134 & ,000 & ,394 & 1,059 \\
\hline & Kehandalan & 267 & ,052 & 271 & 5,149 &, 000 & ,394 & 6,064 \\
\hline & Daya Tanggap & ,083 & ,037 & 085 & 2,256 & ,026 & ,395 & 4,651 \\
\hline & Jaminan & ,266 & ,032 & 272 & 8,448 &, 000 & ,396 & 4,410 \\
\hline & Empati & ,762 & ,082 & ,766 & 9,289 &, 000 & ,398 & 1,870 \\
\hline
\end{tabular}

a. Dependent Variable: Kepuasan Pelanggan

Sumber: Data diolah dengan menggunakan SPSS 25, 2020.

Dari data di atas nilai tolerance dari varibel X adalah 0,394, 0,394, 0,395, 0,396, dan 0,398 lebih besar dari 0,10. Sementara nilai VIF untuk variabel $X$ adalah 1,059, 6,064, 4,651, 4,410, 1,870 lebih kecil dari 10,00. Maka mengacu pada dasar pengambilan keputusan dalam uji multikolinearitas dapat disimpulkan bahwa tidak terjadi gejala multikolinearitas dalam model regresi. 


\section{f. Uji Heterokedastisitas Gambar Uji Heterokedastisitas}

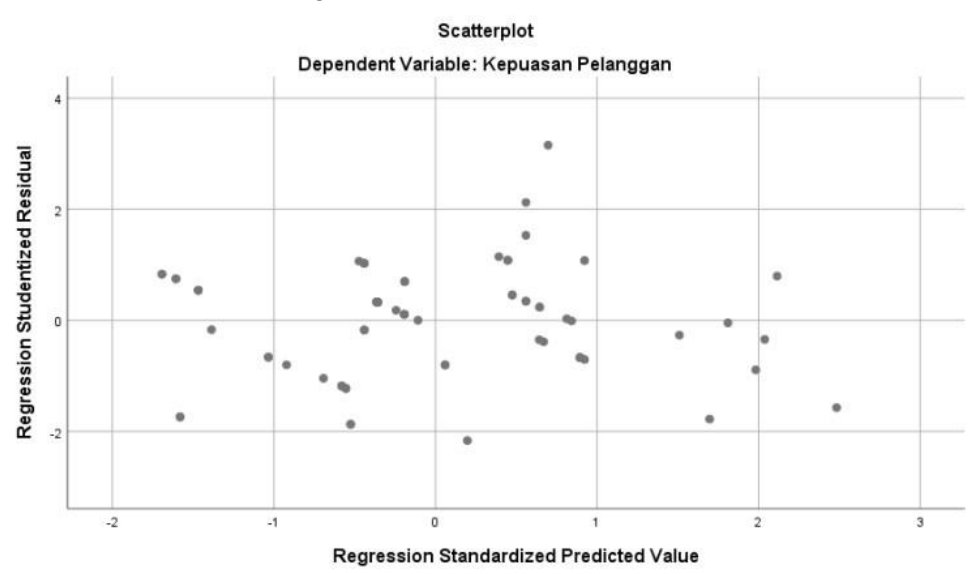

Sumber: Data diolah dengan menggunakan SPSS 25, 2020.

Berdasarkan hasil uji di atas dapat disimpulkan bahwa tidak terdapat gejala heterokedastisitas karena titik-titik data menyebar di atas dan di bawah/disekitar angka 0 , titik-titik data tidak mengumpul diatas dan dibawah saja, dan penyebaran titik-titik data sebaiknya tidak berpola. 3. Uji Hipotesis

\section{a. Uji Parsial Tabel 12 Uji Parsial Coefficientsa}

\begin{tabular}{ll|r|r}
\multicolumn{1}{l}{ Model } & \multicolumn{1}{l|}{$\mathrm{t}$} & \multicolumn{1}{c}{ Sig. } \\
\hline 1 & (Constant) &, 007 &, 995 \\
\cline { 2 - 4 } & Bukti Fisik & 5,134 &, 000 \\
\cline { 2 - 4 } & Kehandalan & 5,149 &, 000 \\
\hline Daya Tanggap & 2,256 &, 026 \\
\hline Jaminan & 8,448 &, 000 \\
\hline Empati & 9,289 &, 000 \\
\hline
\end{tabular}

a. Dependent Variable: Kepuasan Pelanggan

Sumber: Data diolah dengan menggunakan SPSS 25, 2020.

Dari hasil penelitian tabel di atas menunjukkan hasil parsialnya pada variabel sebagai berikut :

1) Variabel bukti fisik dengan nilai thitung adalah 5,134 dan signifikansi 0,000 selanjutnya nilai thitung dibandingkan dengan nilai $t_{\text {tabel }}$ adalah 5,134> 1,00162 dan signifikansi $0,000<0,05$ artinya secara parsial bukti fisik berpengaruh positif dan signifikan terhadap kepuasan pelanggan Apotek Kimia Farma Rantauprapat.

2) Variabel kehandalan dengan nilai thitung adalah 5,149 dan signifikansi 0,000

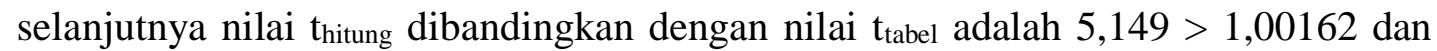
signifikansi $0,000<0,05$ artinya secara parsial variabel kehandalan berpengaruh positif dan signifikan terhadap kepuasan pelanggan Apotek Kimia Farma Rantauprapat. 
3) Variabel daya tanggap dengan nilai thitung adalah 2,256 dan signifikansi 0,026

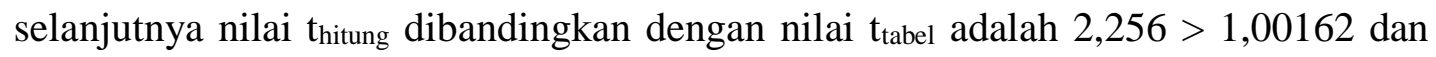
signifikansi $0,026<0,05$ artinya secara parsial daya tanggap berpengaruh positif dan signifikan terhadap kepuasan pelanggan Apotek Kimia Farma Rantauprapat.

4) Variabel jaminan dengan nilai $t_{\text {hitung }}$ adalah 8,448 dan signifikansi 0,000 selanjutnya nilai thitung dibandingkan dengan nilai $t_{\text {tabel }}$ adalah 8,448 > 1,00162 dan signifikansi 0 , $000<0,05$ artinya secara parsial jaminan berpengaruh positif dan signifikan terhadap kepuasan pelanggan Apotek Kimia Farma Rantauprapat.

5) Variabel empati dengan nilai thitung adalah 9,289 dan signifikansi 0, 000 selanjutnya nilai thitung dibandingkan dengan nilai $t_{\text {tabel }}$ adalah 9,289>1,00162 dan signifikansi 0 , $000<0,05$ artinya secara parsial empati berpengaruh positif dan signifikan terhadap kepuasan pelanggan Apotek Kimia Farma Rantauprapat.

\section{b. Uji Simultan Tabel 13 Uji Simultan ANOVA ${ }^{a}$}

\begin{tabular}{l|r|r|r|r|r} 
Model & Sum of Squares & df & Mean Square & $F$ & Sig. \\
\hline 1 & 973,928 & 5 & 194,786 & 16254,664 &, $000^{\mathrm{b}}$ \\
\hline $\begin{array}{l}\text { Regression } \\
\text { Residual }\end{array}$ & 1,102 & 92 &, 012 & & \\
\hline Total & 975,031 & 97 & & & \\
\hline
\end{tabular}

a. Dependent Variable: Kepuasan Pelanggan

b. Predictors: (Constant), Empati, Jaminan, Daya Tanggap, Kehandalan, Bukti Fisik Sumber: Data diolah dengan menggunakan SPSS 25, 2020.

Uji F-test untuk menguji pengaruh simultan pada faktor-faktor yang mempengaruhi kepuasan pelanggan yaitu bukti fisik, kehandalan, daya tanggapm jaminan dan empati yang ditunjukkan pada nilai $F_{\text {hitung }}$ sebesar 16254,664 dan signifikasni 0,000 secara statistic $F_{\text {hitung }}>F_{\text {tabel }}$ atau 16254,664 2,77 dan tingkat signifikansi 0,000 $<0,05$ artinya bukti fisik, kehandalan, daya tanggap jaminan dan empati secara bersama-sama (simultan) berpengaruh positif signifikan terhadap kepuasan pelanggan Apotek Kimia Farma Rantauprapat atau hipotesis diterima.

\section{c. Uji Determinan Tabel 14 Uji Determinan}

\section{Model Summary}

\begin{tabular}{lc|c|c|c} 
Model & $\mathrm{R}$ & $\mathrm{R}$ Square & $\begin{array}{c}\text { Adjusted R } \\
\text { Square }\end{array}$ & $\begin{array}{c}\text { Std. Error of the } \\
\text { Estimate }\end{array}$ \\
\hline 1 &, $977^{\mathrm{a}}$ &, 953 &, 954 &, 109 \\
\hline
\end{tabular}

a. Predictors: (Constant), Empati, Jaminan, Daya Tanggap, Kehandalan, Bukti Fisik

Sumber: Data diolah dengan menggunakan SPSS 25, 2020. 
Dari data di atas angka $\mathrm{R}$ sqaure $=0,953$ yang berarti secara bersama-sama variabel independen mempengaruhi variabel dependen sebesar 95,3\% sedangkan sisanya 4,7\% dipengaruhi oleh variabel lain di luar model.

\section{E. PENUTUP}

Berdasarkan pembahasan hasil penelitian dapat ditarik beberapa kesimpulan:

1. Secara parsial bahwa bukti fisik berpengaruh positif dan signifikan terhadap kepuasan pelanggan Apotek Kimia Farma Rantauprapat, dengan nilai t hitung adalah 5,134 dan signifikansi 0,000 .

2. Secara parsial kehandalan berpengaruh positif dan sangat signifikan terhadap kepuasan pelanggan Apotek Kimia Farma Rantauprapat, dengan nilai t hitung adalah 5,149 dan signifikansi 0,000 .

3. Daya tanggap berpengaruh positif dan signifikan terhadap kepuasan pelanggan Apotek Kimia Farma Rantauprapat, dengan nilai t hitung adalah 2,256 dan signifikansi 0,026.

4. Jaminan berpengaruh positif dan signifikan terhadap kepuasan pelanggan Apotek

Kimia Farma Rantauprapat, dengan nilai t hitung adalah 8,448 dan signifikansi 0,000.

5. Empati berpengaruh positif dan signifikan terhadap kepuasan pelanggan Apotek Kimia Farma Rantauprapat, dengan nilai t hitung adalah 9,289 dan signifikansi 0,000.

6. Variabel daya tanggap memiliki pengaruh yang paling kecil diantara variabel-variabel lain pada penelitian ini.

7. Secara simultan bahwa bukti fisik, kehandalan, daya tanggap jaminan dan empati berpengaruh signifikan terhadap kepuasan pelanggan Apotek Kimia Farma

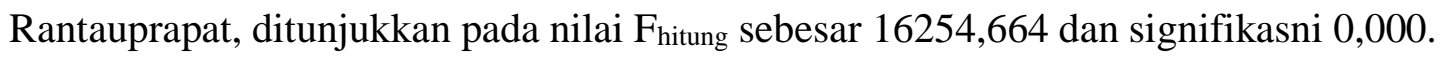

\section{DAFTAR PUSTAKA}

Dominici, G., \& Guzzo, R. 2010. Cust omer sat isfact ion in the hot el indust ry: A case study from Sicily. Internatioal Journal of Marketing Studies, 2(2), 3-12

Kotler Philip, \& Amstrong, G (2010), Principle Of Marketing. Upper saddle River, N.J : Pearson Prentice Hall. 
Kotler, Philip \& Keller, Kevin Lane. 2009. Edisi ketiga belas. Jilid 1. Manajemen Pemasaran. Terjemahan oleh Bob Sabran MM. Jakarta: Erlangga.

Tauriana, Dian. 2012. Analisis pengaruh CRM terhadap citra perusahaan dan dampaknya terhadap loyalitas pelanggan (studi khasus: After sales services product broadband internet JABODETABEK 2012 dikantor pusat PT. XYZ).

Tjiptono, F \& Chandra, G. (2011). Service, Quality and Satisfaction (ed 3). Yogyakarta. Andi. 